\title{
Concentration of a Major Outer Membrane Protein at the Cell Poles in Escherichia coli
}

\author{
By KENNETH J. BEGG* AND W. D. DONACHIE \\ Department of Molecular Biology, University of Edinburgh, Edinburgh EH9 3JR, UK
}

(Received 16 March 1984)

\begin{abstract}
Autoradiography of cell envelope ghosts obtained from a strain of Escherichia coli which lacks two major outer membrane proteins has been used to demonstrate the polar concentration of another major outer membrane protein, $o m p A$ protein. The $\beta$-lactam antibiotic cephalexin prevents the insertion of newly synthesized $\operatorname{omp} A$ protein into the poles but removal of the antibiotic allows the randomly dispersed protein to migrate to the polar and possibly the septal areas of the cell. Labelling of whole cells with bacteriophage K3 has confirmed a polar concentration of $o m p A$ protein.
\end{abstract}

\section{INTRODUCTION}

The outer membrane of Escherichia coli contains a few major species of proteins which are present in large numbers of copies per cell (Henning et al., 1973a,b; Hindennach \& Henning, 1975), together with many other proteins present in much smaller amounts. In a previous communication (Begg, 1978) experiments were described which showed that matrix proteins $(o m p C, o m p F)$ (Endermann et al., 1978) were inserted into the outer membrane of $E$. coli at random locations and that they did not remain fixed at the original sites of insertion. This report is concerned with the distribution of another major outer membrane protein of $E$. coli, ompA protein (Endermann et al., 1978). In contrast to matrix protein, this protein appears normally to be concentrated at the cell poles.

Henning et al. (1973a) have described a technique for obtaining from $E$. coli cell ghosts which consist largely of only four major outer membrane proteins: I (matrix proteins), II (derived from the action of trypsin on $o m p A$ protein), III (see Garten et al., 1975; Hindennach \& Henning, 1975) and IV (lipoprotein; Braun \& Rehn, 1969). This technique has been slightly modified to facilitate the production of ghosts from strains of $E$. coli which lack either matrix proteins or matrix proteins and $o m p A$ protein.

Lipoprotein does not contain histidine (Braun \& Rehn, 1969). Consequently, using radioactive histidine labelling of the appropriate mutants, cell ghosts can be prepared which contain only one or two labelled major outer membrane proteins. Ghosts of this kind were used to study the localization of $o m p A$ protein under various conditions.

An alternative experimental approach, using bacteriophage $\mathrm{K} 3$, was applied to whole cells with normal outer membrane proteins. Bacteriophage $\mathrm{K} 3$, which uses $o m p A$ protein as the protein part of its receptor (Alphen et al., 1977), was used as a 'label' for ompA protein in electron microscopy studies.

\section{METHODS}

Strains and growth conditions. The E. coli strains were: $\mathrm{P} 400$ (Skurray et al., 1974), $\mathrm{F}^{-}$thi argE proA thr leu mtl xyl ara galK lac Y rpsL supE non; $\mathrm{P} 530 \mathrm{H}$, a variant of $\mathrm{P} 400$ lacking matrix proteins, $\mathrm{F}^{-}$thi arg E proA thr leu mtl $x y l$ ara galK lacYompB; P530HK3, a variant of $\mathrm{P} 530 \mathrm{H}$ resistant to bacteriophages $\mathrm{K} 3$ and Tull* lacking ompA protein. Cells were grown in minimal medium (M9 salts; Adams, 1959) plus $0.2 \%$ glucose plus Casamino acids at $0.4 \%$, or required amino acids at $20 \mathrm{mg} \mathrm{ml}^{-1}$, in a shaking water bath at $37^{\circ} \mathrm{C}$. 


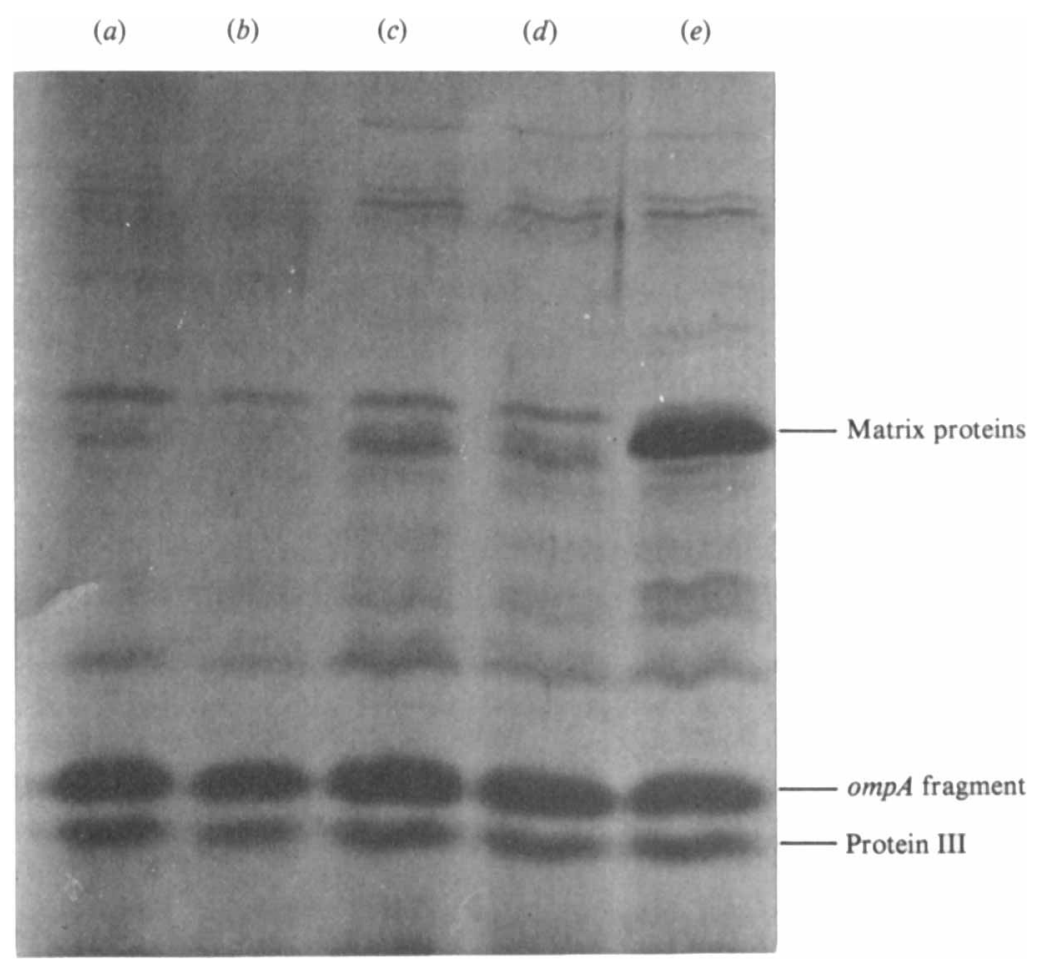

Fig. 1. Stained polyacrylamide gel after electrophoresis of proteins from cell ghosts of: $(a, b) \mathrm{P} 530 \mathrm{H}$ cells treated with cephalexin; $(c, d) \mathrm{P} 530 \mathrm{H}$ cells untreated; (e) $\mathrm{P} 400$ cells untreated. The positions of matrix proteins (which run together in this gel system), of the ompA protein fragment, and of protein III, are indicated.

Ghost preparation. The technique used was essentially that described by Henning et al. (1973a) as procedure II. The sacculus, however, was kept intact by omitting the lysozyme procedure because strains lacking matrix proteins and $o m p A$ protein will not form stable rod-shaped ghosts after the mucopeptide has been removed (unpublished observation).

Polyacrylamide gel analysis (Lutkenhaus, 1977) of wild-type cell ghosts obtained by this procedure showed one dense band at mol. wt approx. 36000 (matrix proteins), a dense band at mol. wt approx. 19000 (the tryptic fragment of $o m p A$ protein), a third, less-dense band at mol. wt approx. 18000 (protein III), and several minor bands (see Fig. 1). Protein IV, lipoprotein, being covalently bound to the intact sacculus, would not enter the gel. The appearance of the tryptic fragment of ompA protein at mol. wt 19000 was surprising, as the original report gave a molecular weight of approx. 28000 (Henning et al., 1973b) and more recent reports suggest a molecular weight of 24000 (Muhlradt \& Golecki, 1975). The identity of the band at mol. wt 19000 was checked by analysing cell envelope preparations, before and after trypsin treatment, on polyacrylamide gels. In addition, Henning's ghost preparations were analysed in similar fashion before and after trypsin treatment. In both cases the dense band at mol. wt 33000 (ompA protein) disappeared after treatment with trypsin and a new dense band appeared at mol. wt 19000 (see Fig. 2).

Ghosts prepared from strain P530H lacked the dense band at mol. wt 36000 and ghosts from strain P530HK3 lacked the dense bands at mol. wt 36000 and mol. wt 19000. Protein III and the minor bands were still present in ghosts prepared from both these strains (see Fig. 3).

Labelling with $\left[{ }^{3} \mathrm{H}\right]$ histidine and autoradiography. The techniques used have been described previously (Begg, 1978).

Autoradiograms were examined in a Zeiss photo-microscope and photographs were taken using Pan-F film (Ilford). Prints were made and the position of the grains along each cell were measured. Grain positions were expressed as fractional distances from the nearer of the two cell poles. Fractions of $5 \%$ of cell length were used for filamentous cells and fractions of $10 \%$ for cells of normal length. 

(a)
(b)
(c)
(d)
(e)

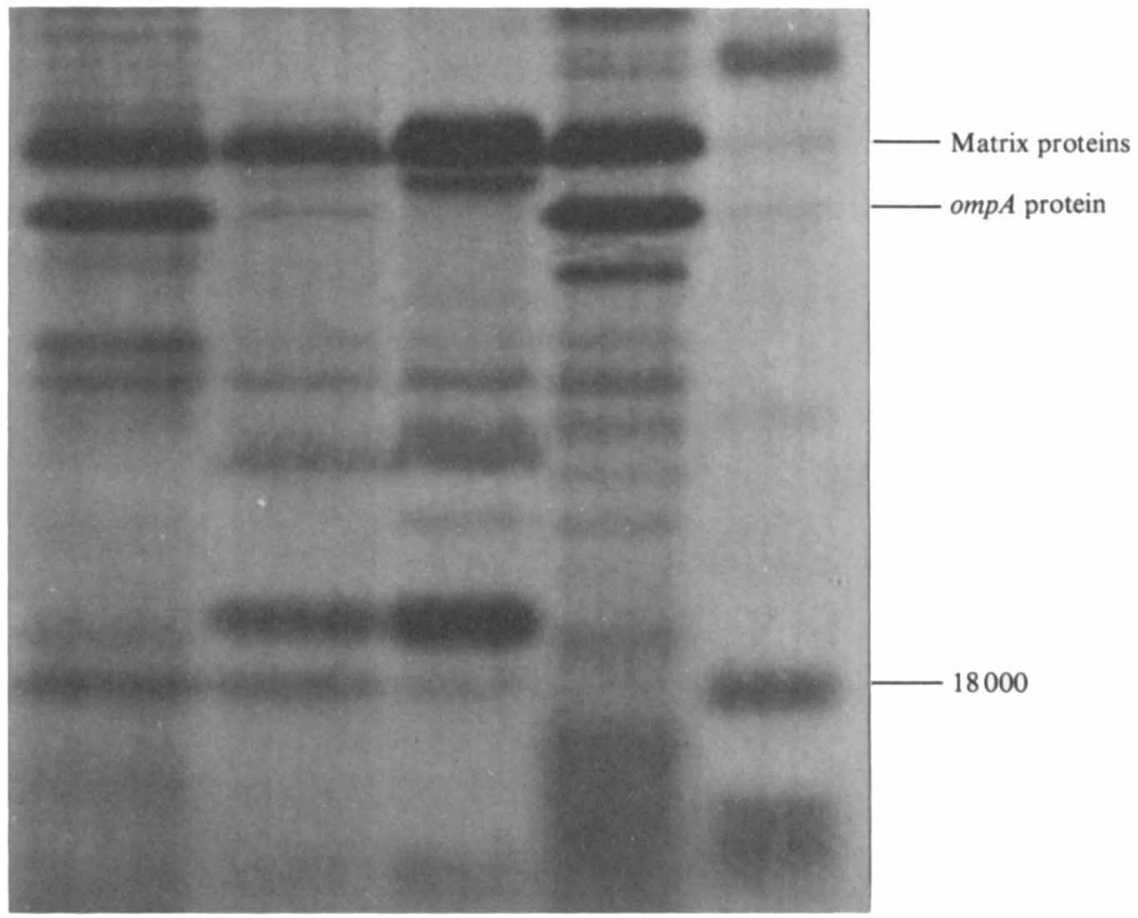

Fig. 2. Stained SDS polyacrylamide gel showing: (a) cell envelopes of P400; $(b)$ cell envelopes of P400 after treatment with trypsin; $(c)$ a ghost preparation of P400 immediately after trypsin treatment; $(d)$ the same preparation immediately before trypsin treatment; and $(e)$ molecular weight standards, in descending order from the top, $68000,42000,18000,14000,11700$. The positions of matrix proteins (which migrate together) and the ompA protein are indicated, together with the 18000 molecular weight standard.

Cephalexin was a generous gift from Eli Lilly \& Co., and was used at $40 \mu \mathrm{g} \mathrm{ml}^{-1}$. Nalidixic acid was used at $20 \mu \mathrm{g} \mathrm{ml}^{-1}$.

K3 labelling technique. Cells were grown to a density of approx. $2 \times 10^{8} \mathrm{ml}^{-1}$ in Oxoid Nutrient Broth no. 2 and 2 vols culture were mixed with 1 vol. $\mathrm{K} 3$ phage lysate (approx. $8 \times 10^{10}$ p.f.u. $\mathrm{ml}^{-1}$ ) to give a phage multiplicity of 200 per bacterium. Adsorption was stopped by adding 3 vols glutaraldehyde fixative [ $5 \mathrm{ml}$ glutaraldehyde (TAAB Laboratories, Reading, UK), $20 \mathrm{ml} 0.1 \mathrm{M}$-phosphate buffered saline $\mathrm{pH} 7 \cdot 4]$. Cells were pelleted and resuspended in glutaraldehyde fixative for $1 \mathrm{~h}$. This procedure was followed by washing three times in distilled water.

\section{RESULTS}

Fig. 4(a) shows the grain distribution obtained when ghosts were prepared from $E$. coli P400 cells which had been pulsed with $\left[{ }^{3} \mathrm{H}\right]$ histidine for $10 \mathrm{~min}$ immediately before ghost preparation. Strain P400 contains all major outer membrane proteins. The distribution shows label over the whole cell surfaces with a slight excess at the poles. Fig. $4(b)$ shows the grain distribution obtained in the same way with P530HK 3 cells, which lack matrix proteins (ompC and ompF) and ompA protein. The pattern is very similar to that obtained with P400. Fig. 4(c) shows the grain distribution obtained when $\mathrm{P} 530 \mathrm{H}$ cells were treated in similar fashion. P530H lacks matrix proteins ( $o m p C$ and $o m p F$ ), due to a mutation in the regulatory gene $o m p B$, but does contain omp $A$ protein. omp $A$ protein is responsible for $40 \%$ of the radioactive label in the ghosts (data not shown). The distribution of grains obtained with strain $\mathrm{P} 530 \mathrm{H}$ is clearly non-random, 
(a)

(b)

(c)

(d)

(e)

(f)

(g)

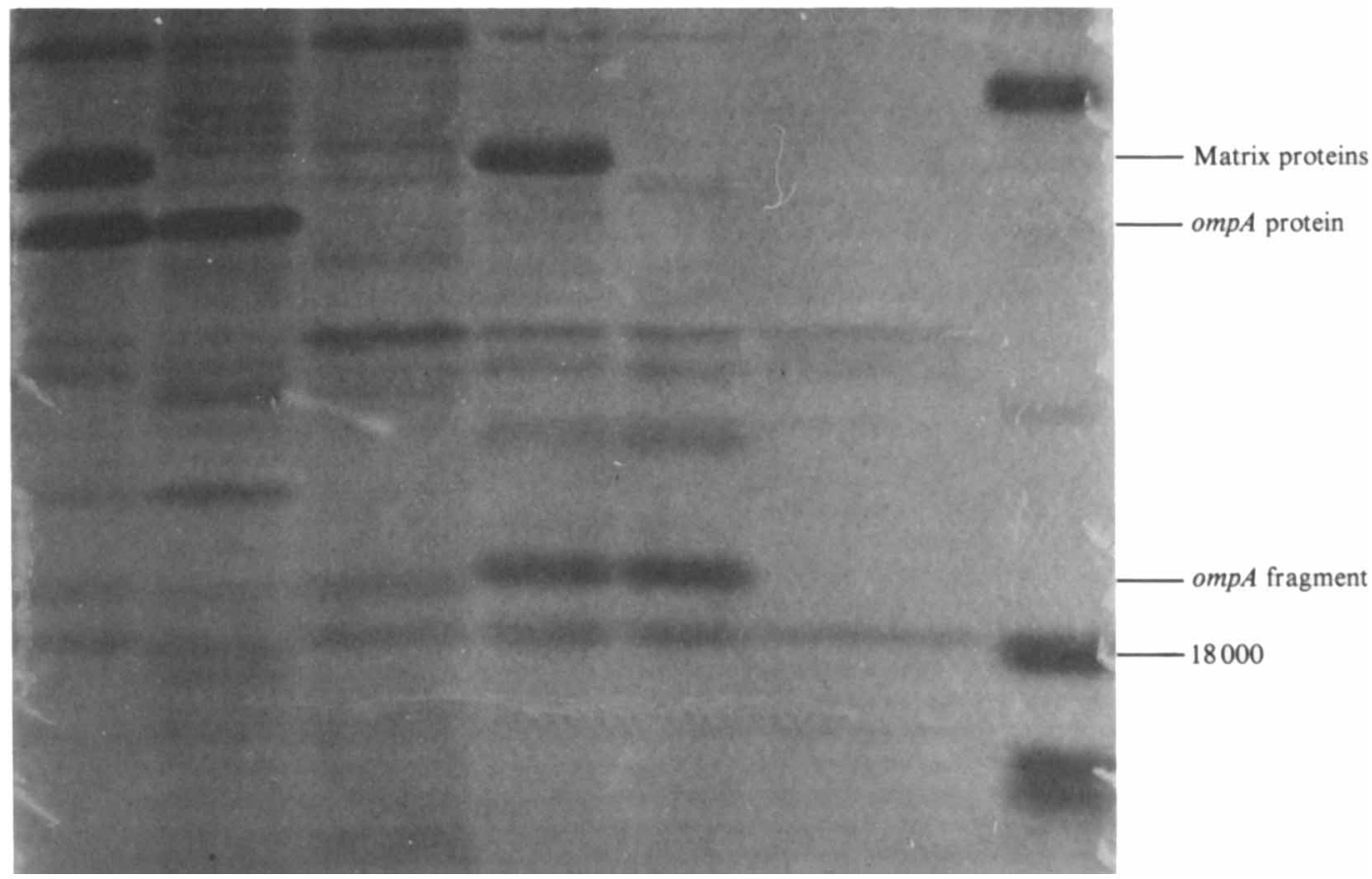

Fig. 3. Stained SDS polyacrylamide gel showing: cell envelope proteins of (a) P400, (b) P530H, (c) P530HK 3; cell ghosts from $(d) \mathrm{P} 400,(e) \mathrm{P530H},(f)$ P530HK 3; and molecular weight standards $(g)$ in descending order $68000,42000,18000,14000,11700$. The positions of matrix proteins, omp $A$ protein, the tryptic fragment of $o m p A$ protein and the 18000 molecular weight standard, are indicated.

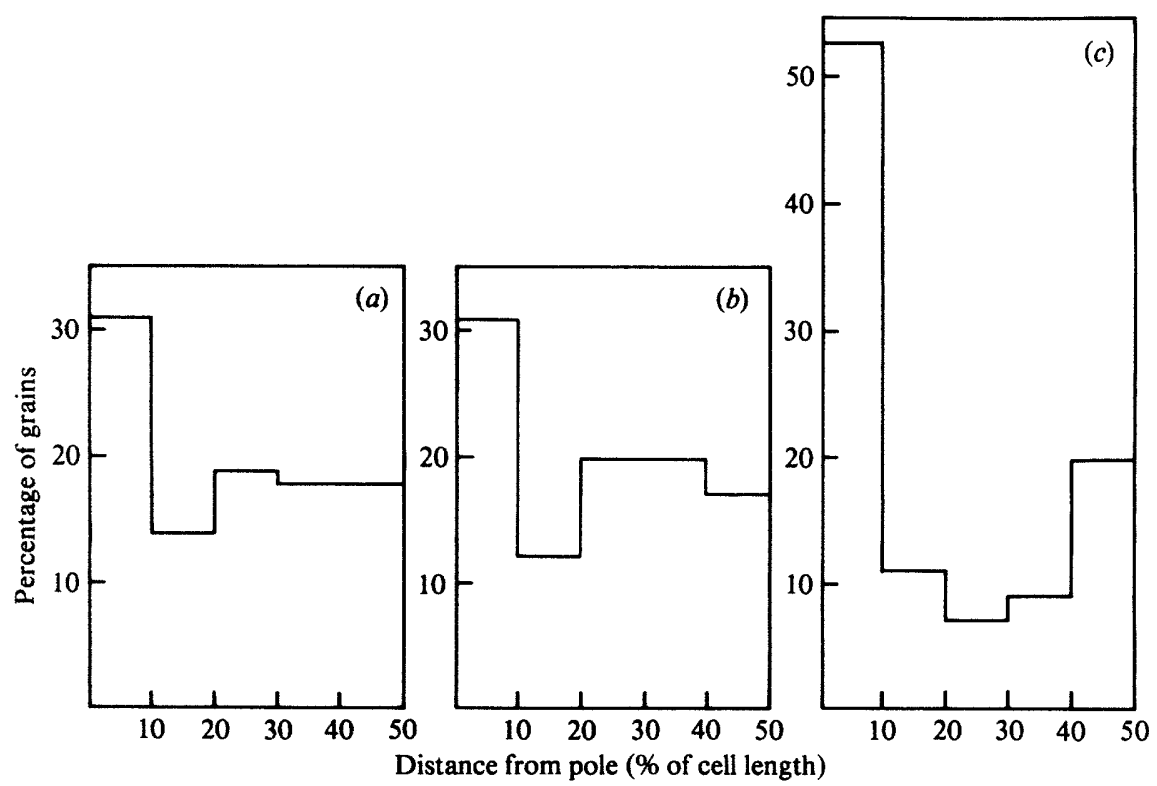

Fig. 4. Distribution of grains as a function of relative distance from the pole in cell ghosts of $E$. coli. Cells were pulse-labelled with [ $\left.{ }^{3} \mathrm{H}\right]$ histidine for $10 \mathrm{~min}$ immediately before ghost preparation. (a) P400 (188 grains measured), (b) P530HK3 (309 grains measured), (c) P530H (278 grains measured). 


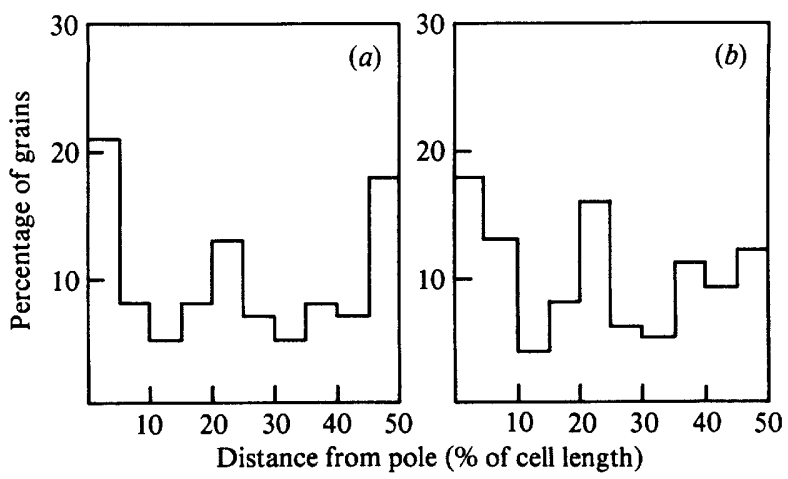

Fig. 5. (a) Distribution of grains (336 grains measured) in cells ghosts of $E$. coli P530H. Cells were pulselabelled as in Fig. 1 then chased with non-radioactive histidine and allowed to grow for one mass doubling in the presence of cephalexin, to inhibit division. (b) Cells treated as in (a) but grown for two mass doublings in the presence of cephalexin ( 342 grains measured).

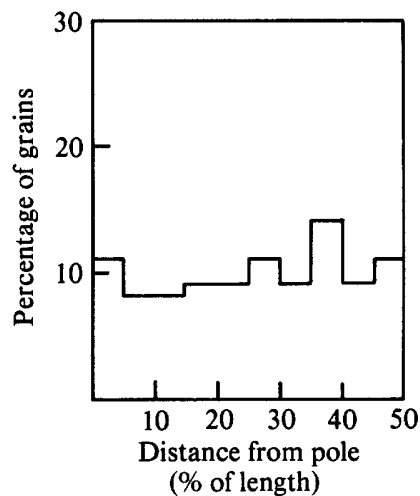

Fig. 6. Distribution of grains (488 grains measured) in cell ghosts of $E$. coli $\mathrm{P} 530 \mathrm{H}$. Cells were treated with cephalexin for 1.5 mass doublings, and pulse-labelled with $\left[{ }^{3} \mathrm{H}\right]$ histidine in the presence of cephalexin for $10 \mathrm{~min}$ immediately before ghost preparation.

with a high degree of polar labelling and an indication of a second concentration at the cell centre, where new poles will form.

Fig. 5 shows the distribution of grains obtained when cells of $\mathrm{P530H}$ were pulsed with radioactive histidine for $10 \mathrm{~min}$, chased with non-radioactive histidine and allowed to continue growing in the presence of cephalexin (Nishima \& Nakazawa, 1973) to inhibit division for $(a)$ one mass doubling or $(b)$ two mass doublings. The labelled protein in both cases is predominantly found at the poles and at regions which would be the sites of new poles if the filaments were allowed to divide, i.e. $25 \%$ and $50 \%$ of the cell length (unpublished observation). Fig. 6 shows the result of labelling pre-formed cephalexin-induced filaments of P530H with radioactive histidine in the presence of cephalexin. This time the grains are randomly distributed over the entire surface of the ghosts.

The presence of cephalexin did not alter the protein composition of the ghosts (see Fig. 1), neither did it enhance or inhibit the incorporation of radioactive histidine (data not shown).

Fig. 7 shows the result of an experiment in which cephalexin-induced filaments of P530H were pulse-labelled with radioactive histidine in the presence of cephalexin. The cephalexin was then removed and the cells were allowed to continue growing. Samples were taken for ghost preparation at $(a) 0 \mathrm{~min},(b) 15 \mathrm{~min}$ and $(c) 30 \mathrm{~min}$ after the removal of cephalexin. The observed distributions suggest that the labelled protein which is randomly distributed after incubation 


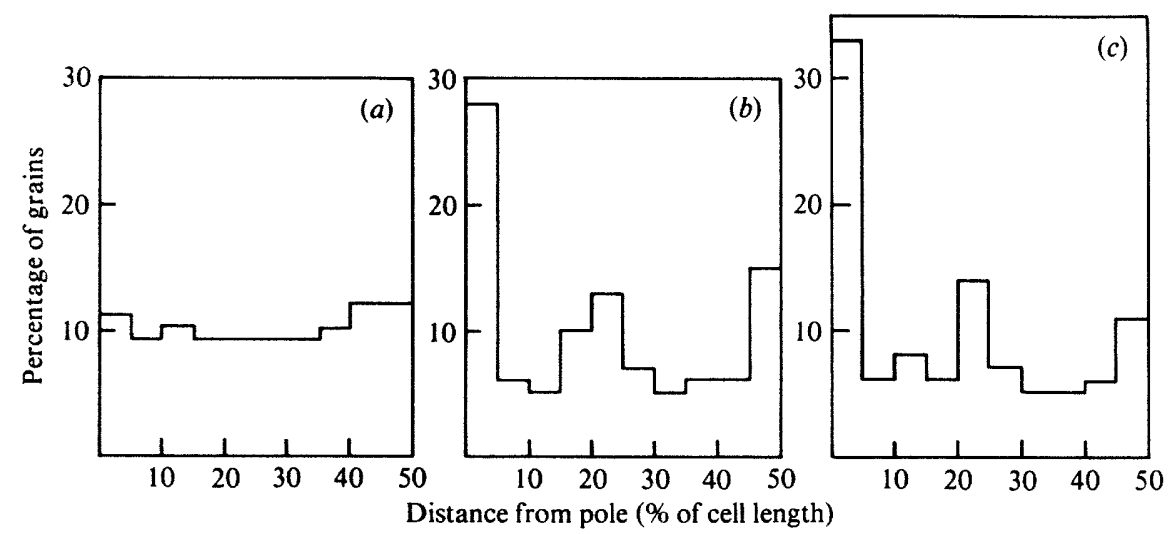

Fig. 7. Cells of $E$. coli $\mathrm{P} 530 \mathrm{H}$ were treated with cephalexin for one mass doubling, pulse-labelled in the presence of cephalexin for $10 \mathrm{~min}$, washed free of cephalexin and allowed to continue growth. Ghosts were prepared as before. (a) Distribution of grains ( 360 grains on 112 cells) at 0 min after removal of cephalexin. (b) Distribution of grains (422 grains on 170 cells) at $15 \mathrm{~min}$ after removal of cephalexin. $(c)$ Distribution of grains (422 grains on 170 cells) at 30 min after removal of cephalexin.

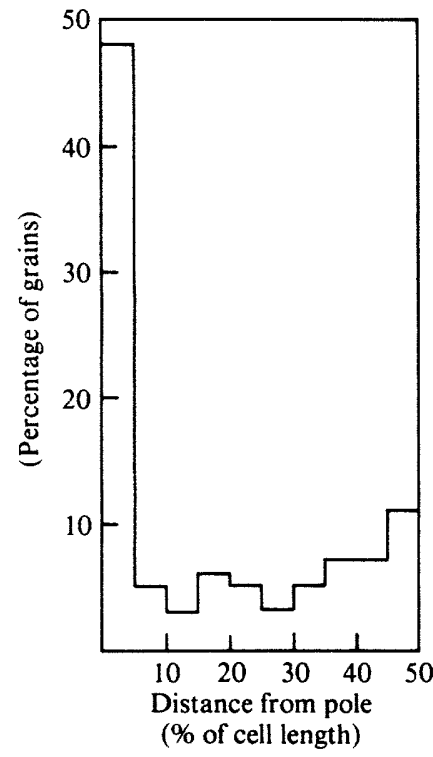

Fig. 8

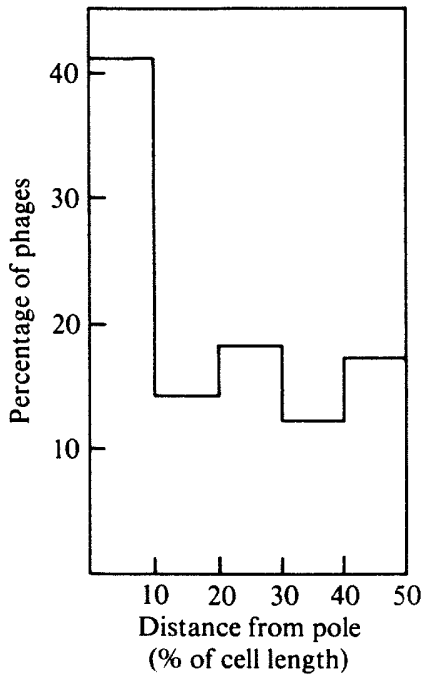

Fig. 9

Fig. 8. Distribution of grains (460 grains measured) in cell ghosts of $E$. coli $\mathrm{P} 530 \mathrm{H}$. Cells were treated with nalidixic acid for one mass doubling and pulse-labelled with $\left[{ }^{3} \mathrm{H}\right]$ histidine for $10 \mathrm{~min}$ in the presence of nalidixic acid immediately before ghost preparation.

Fig. 9. Distribution of bacteriophage K 3 on the surface of cells of $E$. coli P400 after a 2 min adsorption period (560 phage measured).

with cephalexin can mobilize and relocate at polar and prospective polar regions after the removal of cephalexin. [Note: cell division re-starts between 30 and $40 \mathrm{~min}$ after the removal of cephalexin in this strain under these experimental conditions.]

It could be argued that the localization of the $\operatorname{omp} A$ protein at the poles of the cell ghosts might 
have arisen by loss of the $o m p A$ protein fragment from non-polar regions only, during ghost preparation. However, such an explanation would also imply that the presence of cephalexin during cell growth would prevent this happening, although even then only to those $o m p A$ protein molecules which were synthesized in the presence of cephalexin. If this were so, then ghosts of cells labelled in the presence of cephalexin should contain more label than ghosts from cells labelled in its absence. Counts of the number of grains per cell in the experiment shown in Fig. 7 showed that this is not the case: there was no significant difference between the three samples. Grains per cell values were: $0 \mathrm{~min}, 3 \cdot 2 ; 15 \mathrm{~min}, 2 \cdot 9 ; 30 \mathrm{~min}, 2 \cdot 5$. [Autoradiograms from all three samples were exposed for the same time, so the grains per cell value for each is a true reflection of the amount of labelled protein per cell.] From the numbers of grains per cell and the distribution of the grains as a function of relative distance from the pole the average number of grains per pole can be calculated. The respective values were: $0 \mathrm{~min}, 0.35 ; 15 \mathrm{~min}, 0.81 ; 30 \mathrm{~min}$, 0.83 (taking the pole as the first $5 \%$ of cell length). This demonstrates that the appearance of the polar label pattern after removal of cephalexin is due to an increase in labelled protein at the poles and not to loss from other areas.

To ascertain whether or not filamentation, in general, was responsible for the random distribution observed when pulse-labelling filaments in the presence of cephalexin, filaments of $\mathrm{P} 530 \mathrm{H}$ were induced by nalidixic acid and pulse-labelled with radioactive histidine in the presence of this antibiotic. This time the grain distribution was non-random (Fig. 8), suggesting that the action of cephalexin was responsible for the random location of a protein which otherwise appears to be concentrated in polar areas.

The bacteriophage K3 adsorbs specifically to ompA protein (Alphen et al., 1977). It can therefore be used to reveal the location of $\operatorname{omp} A$ protein in intact cells. Fig. 9 shows the distribution of bacteriophage K3 adsorbed to the surface of P400 cells after a 2 min labelling procedure. Although the receptor sites are not confined to the poles, there is a predominance of $\mathrm{K} 3$ adsorbed at the poles.

\section{DISCUSSION}

The experiments outlined in this report suggest that a major outer membrane protein of $E$. coli, omp $A$ protein, is predominantly located at the poles of cell envelopes. Newly synthesized $o m p A$ protein appears to be inserted at these sites during normal cell growth. Furthermore, the $\beta$-lactam antibiotic cephalexin, which blocks cell division (i.e. pole formation), prevents polar concentration of this protein, but upon removal of cephalexin, the randomly distributed protein can mobilize and relocate at polar sites before cell division resumes.

These results are surprising, particularly as work on other major outer membrane proteins in Gram-negative bacteria has shown that they are inserted and distributed randomly in the outer membrane (Begg, 1978; Smit \& Nikaido, 1978). The data in this report are derived from the distribution of the tryptic fragment of $o m p A$ protein and not from $o m p A$ protein itself. This fragment has been studied in some detail (Schweizer et al., 1978) and in the presence of lipopolysaccharide was found to exhibit the phage receptor activity of $o m p A$ protein. Lipopolysaccharide is only found at the outer surface of the outer membrane (Muhlradt \& Golecki, 1975) so it may well be that the tryptic fragment is the outer part of the protein which has been shown to be transmembrane (Endermann et al., 1978).

Cephalexin inhibits division by inhibiting cross-bridge formation by the peptidoglycan transpeptidase action of penicillin-binding protein 3, which is specifically required for septum formation (Ishino \& Matsuhashi, 1981). Mutants which are temperature-sensitive for the production of penicillin-binding protein 3 have been described (Spratt, 1977) and these mutants produce filaments at the restrictive temperature. Preliminary 'ghost' labelling experiments in filaments induced by such a temperature-sensitive mutation have not, however, shown the random labelling pattern observed when cephalexin was present (data not shown). The label was strongly polar as in the case of filaments induced by nalidixic acid.

Although mutant strains of $E$. coli which lack omp $A$ protein can grow and divide normally 
(Henning \& Haller, 1975), ompA protein has been suggested to play a role in cell morphogenesis because cells lacking both omp $A$ protein and lipoprotein lose their normal rod shape and grow as spheres (Sonntag et al., 1978). The absence of lipoprotein alone does not mediate this change.

Buchanan (1981) has reported the uneven distribution of penicillin-binding protein 2 (PBP2) in the $E$. coli cell membrane, and has discussed the possibility that its specialized function in cell elongation may be determined by its uneven distribution. Similar consideration might be given to $o m p A$ protein. The polar concentration of $o m p A$ protein might be required for the shaping of the hemispherical cell poles which form at each cell division.

We are grateful to David T. Veitch for photographic work connected with this manuscript.

\section{REFERENCES}

ADAMs, M. H. (1959). Bacteriophages, 1st edn, p. 66. New York: Interscience.

ALPHEN, L. VAN, HAVEKes, L. \& LUGTENBERG, B. (1977). Major outer membrane protein d of Escherichia coli $\mathrm{K}-12$ : purification and in vitro activity of bacteriophage $\mathrm{K} 3$ and $\mathrm{F}$-pilus mediated conjugation. FEBS Letters 75, 285-290.

BEGG, K. J. (1978). Cell surface growth in Escherichia coli: distribution of matrix protein. Journal of Bacteriology 135, 307-310.

Braun, V. \& ReHN, K. (1969). Chemical characterization, spatial distribution and function of a lipoprotein (murein lipoprotein) of the $E$. coli cell wall. European Journal of Biochemistry 104, 426 438.

BuChanan, C. E. (1981). Topographical distribution of penicillin-binding proteins in the Escherichia coli membrane. Journal of Bacteriology 145, 1293-1298.

DAvies, J. K. \& ReEves, P. (1975). Genetics of resistance to colicins in Escherichia coli $\mathrm{K}-12$ : cross resistance among colicins of group A. Journal of Bacteriology 123, 102-117.

Endermann, R., Kramer, C. \& Henning, U. (1978). Major outer membrane proteins of Escherichia coli $\mathrm{K}-12$ : Evidence for protein $\mathrm{II}^{*}$ being a transmembrane protein. FEBS Letters 86, 21-24.

Garten, W., Hindennach, I. \& Henning, U. (1975). The major proteins of the Escherichia coli outer cell envelope membrane. Characterization of proteins $\mathrm{II}^{*}$ and III, comparison of all proteins. European Journal of Biochemistry 59, 215-221.

Henning, U. \& Haller, I. (1975). Mutants of Escherichia coli K-12 lacking all 'major' proteins of the outer cell envelope membrane. FEBS Letters 55 , 161-164.

Henning, U., Hoehn, B. \& SonNtag, I. (1973a). Cell envelope and shape of $E$. coli $\mathrm{K}-12$. The ghost membrane. European Journal of Biochemistry 39, 2736.

Henning, U., Rehn, K. \& Hoehn, B. (1973b). Cell envelope and shape of Escherichia coli K-12. Proceedings of the National Academy of Sciences of the United States of America 70, 2033-2036.

HindennaCH, I. \& Henning, U. (1975). The major proteins of the Escherichia coli outer cell membrane. Preparative isolation of all major membrane proteins. European Journal of Biochemistry 59, 207-213.
Ishino, F. \& Matsuhashi, M. (1981). Peptidoglycan synthetic enzyme activities of highly purified penicillin-binding protein 3 in Escherichia coli: a septum forming reaction sequence. Biochemical and Biophysical Research Communications 101, 905-911.

Lugtenberg, B., Meijers, J., Peters, R., Hock, P. \& AlPHEN, L. VAN DER (1975). Electrophoretic resolution of the major outer membrane protein of $E$. coli K-12 into four bands. FEBS Letters 58, 254-258.

LUTKENHAUS, J. F. (1977). Role of a major outer membrane protein in Escherichia coli. Journal of Bacteriology 131, 631-637.

Muhlradt, P. F. \& Golecki, J. R. (1975). Asymmetrical distribution and artifactual re-orientation of lipopolysaccharide in the outer membrane bilayer of Salmonella typhimurium. European Journal of Biochemistry 51, 343-352.

Nishima, T. \& Nakazawa, S. (1973). Cephalexininduced morphological alterations in the surface structures of $S$. aureus and $E$. coli demonstrated by scanning electron microscopy. Japanese Journal of Microbiology 17, 383-392.

Schweizer, M., Hindennach, I. \& Henning, U. (1978). Major proteins of the Escherichia coli outer cell envelope membrane. Interaction of protein $\mathrm{II}^{*}$ with lipopolysaccharide. European Journal of Biochemistry 82, 211-217.

Skurray, R. A., Hancock, R. E. W. \& Reeves, P (1974). Con $^{-}$mutants: class of mutants in Escherichia coli K-12 lacking a major cell wall protein and defective in conjugation and adsorption of a bacteriophage. Journal of Bacteriology 119, 726-735.

Smit, J. \& Nikaido, H. (1978). Outer membrane of Gram-negative bacteria XVIII. Electron microscopic studies on porin insertion sites and growth of cell surface of Salmonella typhimurium. Journal of Bacteriology 135, 687-702.

Sonntag, I., Schwarz, H., Hirota, Y. \& Henning, U. (1978). Cell envelope and shape of Escherichia coli: multiple mutants missing the outer membrane lipoprotein and other major outer membrane proteins. Journal of Bacteriology 136, 280-285.

SpratT, B. G. (1977). Temperature-sensitive cell division mutants of Escherichia coli with thermolabile penicillin-binding proteins. Journal of Bacteriology 131, 293-305. 